\title{
FLORA DIVERSITY, COMPOSITION AND ECOLOGY IN BESIQ BERMAI TROPICAL FOREST OF DAMAI DISTRICT, EAST KALIMANTAN
}

\author{
SITI SOFIAH*, DESTARIO METUSALA, TRIMANTO and SITI NURFADILAH \\ Purwodadi Botanic Garden, Indonesian Institute of Sciences (LIPI), Pasuruan 67163, Indonesia
}

Received 17 November 2016 / Accepted 16 November 2017

\begin{abstract}
Besiq Bermai Forest is part of Kalimantan forests known for vast plant diversity. The present study aimed to investigate flora diversity, composition, and ecology in Besiq Bermai Forest to support the management of biodiversity and forest conservation. Thirteen plots were established with different sizes of plots $(100 \mathrm{~m} \times 20 \mathrm{~m}$ plots for trees; $40 \mathrm{~m}$ x $5 \mathrm{~m}$ plots for saplings; and $5 \mathrm{~m}$ x $5 \mathrm{~m}$ plots for understory). Data recorded included plant species name and individual number of each plant species. Data analysed were Shannon-Wiener diversity index, Relative Density, Relative Frequency, Relative Dominance and Important Value Index. The principal component analysis (PCA) was performed to determine relationship between edaphic components and flora occurrence. The results showed that there were 93 species of trees (belonging to 48 genera and 22 families), 112 species of saplings (belonging to 62 genera and 43 families), and 48 species of understory (belonging to 28 genera and 20 families). Shannon-Wiener diversity index $\left(\mathrm{H}^{\prime}\right)$ were $6.05,6.25$ and 3.26 for tree, saplings and understory, respectively. The most common family for tree and saplings in the forest ecosystem in this area was Dipterocarpaceae (Shorea spp). Species of tree with the highest importance value index were Dillenia excelsa, Syzygium sp. and Shorea parvifolia. The highest importance value index for species of saplings were Macaranga triloba and Shorea parvifolia; and for species of understory were Phrynium jagorianum. Ecological (edaphic) factors affecting the occurence and establishment of flora in Bermai forest were total $\mathrm{N}$ and $\mathrm{C} / \mathrm{N}$ ratio. The present study has implication for the management of biodiversity and forest conservation.
\end{abstract}

Keywords: composition, ecology, flora diversity, Kalimantan, tropical forest

\section{INTRODUCTION}

Tropical forest is one of the hotspots-regions of biodiversity, with high plant diversity, complex ecosystems, and greatest variety of flora and fauna (Richards 1952; Whitmore 1988; de Bruyn et al. 2014). Borneo is recognised as one of the biodiversity hotspots regions, along with 24 other hotspot regions in the world (Marchese 2015). East Kalimantan, located in the eastern part of Borneo, possess thousands of potential plants in the flora diversity of Indonesia. Tropical forest along Indonesia-Malaysia (Indo-Malay region) is known for its largest tropical forest ecosystem in the world (Gaither \& Rocha 2013).

Inventory to investigate plant diversity and floristic composition in natural forests is important to the level of adaptation to the

\footnotetext{
* Corresponding author: sofie2291@yahoo.com
}

environment and their ecological significance (Reddy et al. 2011), and is absolutely essential understanding the forest ecosystem dynamics (Reddy et al.2008). It plays an important role in the management of biodiversity as essential bioresources and in the management of conservation of species and forest ecosystem (Malouin et al. 2015; Lukácz et al. 2013; Meng et al. 2011; Nurfadilah 2015; You et al. 2016; Huang et al. 2016). Plant diversity and floristic composition in several tropical forests addressed for the management of biodiversity and ecosystem conservation have been widely studied accross the world, in Costa Rica (Gilman et al. 2016), in China (Meng et al. 2011), in Ghana (Addo-Fordjour et al. 2009), in Ethiopia (Kebede et al. 2016), in Tanzania (Giliba et al. 2011), in Bangladesh (Feroz et al. 2016).

Despite its great diversity, tropical forests have experienced the highest diversity loss. Tropical 
forests in Indonesia, especially in Kalimantan, is amongst those experiencing higher diversity loss (Bruhl \& Eltz 2010; Margono et al. 2014; Hansen et al. 2009). Approximately $57 \%$ of low land rain forests in Kalimantan conservation area (hutan lindung) has disappeared between 1885-2001 (Gaveau et al. 2013; Stibig et al. 2007). Exploitation of tropical forests, especially in Kalimantan, has occured for a long period (Gaveau et al. 2016). Generally, the loss of forests in Kalimantan has been caused by the land use change into agricultural areas (Busch \& Ferretti-Gallon 2017), plantation of oil palms, and mining. Restoration should be conducted for the recovery of forest ecosystems.

Restoration is vital for recovery of tropical deforestation and degraded land, and for conservation of biodiversity (Ashton et al. 2014; Kettle 2012). In the management of restoration, biodiversity and forest conservation, analysis of the flora diversity and composition, and combined understanding of ecology and environmental factors that influence the diversity in forests is important. The present study aimed to investigate the flora diversity, composition and ecology in Besiq Bermai forest of Damai District in East Kalimantan. The study site was coal mining area targeted for reforestation and restoration after mining (post-mining). The results of the present study on the flora diversity, composition, and ecology of forests is important for the rehabilitation program of coal mining areas.

\section{MATERIALS AND METHODS}

The study was conducted in low land rain tropical forests of village Besiq Bermai of Damai District in East Kalimantan, GPS coordinate $00^{\circ}$ 51'.02.6"S, $115^{0} 26^{\prime} 30.7^{\prime \prime} \mathrm{E}$ (Fig. 1). This forest area was a primary forest that started undergoing degradation and becoming a secondary forest. In the present study, nested plots were established, with stratified random sampling method. Thirteen plots were made with different sizes of plots, out of the total forest area of about 2000 ha; $100 \mathrm{~m} \times 20 \mathrm{~m}$ plots for trees, $40 \mathrm{~m} \times 5 \mathrm{~m}$ plots for saplings, and $5 \mathrm{~m} \times 5 \mathrm{~m}$ plots for understory. Category of trees and saplings were determined by the size of diameter at breast height $(\mathrm{DBH})$ of woody plants; tree $(\mathrm{DBH}>30 \mathrm{~cm})$ and saplings (DBH between $5 \mathrm{~cm}-30 \mathrm{~cm}$ ). Understory are groundcover plants growing on the forest floor which are typically herbs. All plant species within the plots were recorded.

To investigate the floristic composition, some parameters including Shannon-Wiener Diversity Index, Important Value Index, Density (D), Relative Density (RD), Frequency (F), Relative Frequency (RF), Dominance (C) and Relative Dominance $(\mathrm{RC})$ for each species, were analysed.

$$
\begin{aligned}
& \mathrm{RD}=\frac{\text { Number of individuals of a taxon }}{\text { Total number of individuals }} \times 100 \\
& \mathrm{RF}=\frac{\text { Number of plots containing a taxon }}{\text { Total frequencies of all taxa }} \times 100
\end{aligned}
$$

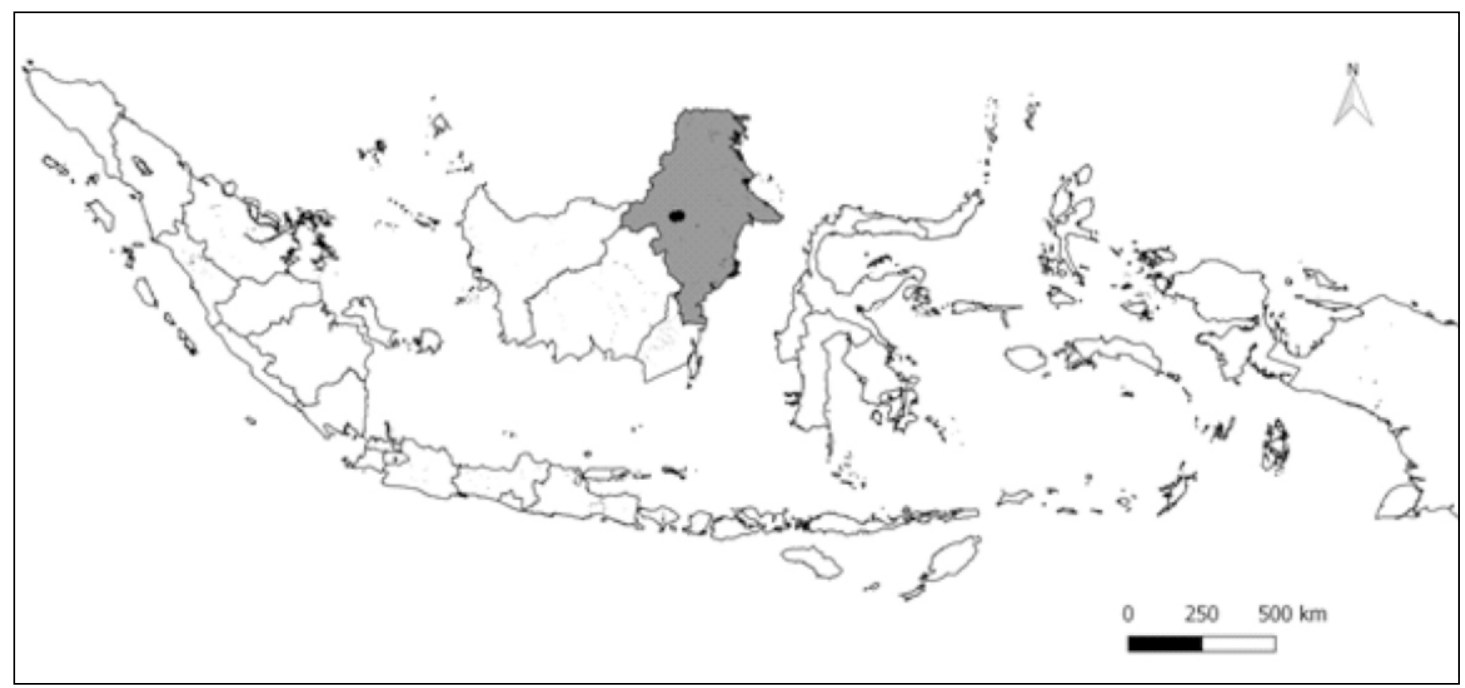

Figure 1 A map of study site area in Besiq Bermai Forest, East Kalimantan, Indonesia 
$\mathrm{RC}=\frac{\text { Basal area of a taxon }}{\text { Total basal area of taxa }} \times 100$

$\mathrm{H}^{\prime}=-\sum p i \ln p i ; p i=n i /$

$n i=$ number of individual from species $-\mathrm{i}$

$\mathrm{N}=$ total number of individual

To analyse edaphic factors that influence the growth and the establishment of flora at the study site, soil samples were collected. Soils were collected in each plot for 3 replicates. The collection of soils for soil physical and chemical profiles were collected from the depth of $0 \mathrm{~cm}$ $30 \mathrm{~cm}$, and $30 \mathrm{~cm}-60 \mathrm{~cm}$ and 3 replicates for each plot.

The soil physicochemical properties were assessed in the soil science laboratory of Agriculture Research Institute of Mulawarman University, Samarinda and were analysed through the drying stage temperature of $105^{\circ} \mathrm{C}$. Soil physical factors analysed included soil texture (sand, silt and clay), while chemistry factors included soil acidity $(\mathrm{pH})$, organic $\mathrm{C}, \mathrm{C} / \mathrm{N}$ Ratio, organic matter $(\mathrm{OM})$ and $\mathrm{N}$-total. Soil texture analysis was conducted by separating sand, silt and clay particles by quantitative method through mechanical analysis process. This process consists of spreading aggregate soil into single grains, followed by sedimentation. Soil acidity $(\mathrm{pH})$ was measured in soil and water mixture extracts with a ratio of 1: 5, C content was analysed by Walkley and Black (1934) method, while total $\mathrm{N}$ was determined by Kjeldahl (1883) method. To investigate ecological factors focussing on edaphic variables that influenced the occurence and the establishment of flora in their habitats, the Principal Component Analysis (PCA) method with Minitab 16 software was used.

\section{RESULTS AND DISCUSSION}

\section{Flora Diversity}

The study showed that the flora diversity in Besiq Bermai forest, East Kalimantan was relatively high. An index of plant diversity of greater than $3(>3)$ is regarded as high-value area (Khan et al. 2012). Plant diversity index indicating the degree of diversity of plants at the study site in the study was high, with the Shannon-Wiener diversity index $\left(\mathrm{H}^{\prime}\right)$ for trees, shrubs and understory in this area being 6.05, 6.25 and 3.26, respectively (Fig. 2). Comparatively, the diversity index at the study site was higher than that of other parts of Kalimantan or Borneo, such as in Lubuk Kakap, West Kalimantan with H' for tree being 3.54 (Budiharta 2010) and in a lowland dipterocarp forest of North Borneo with $\mathrm{H}^{\prime}$ for tree was less than 3.5 (Godoong et al. 2014).

The difference in the degree of diversity at the study site which is located in East Kalimantan and other parts of Kalimantan/Borneo might be due to the difference in regions within Borneo. Guhardja et al. (2012) reported that the diversity varied within Kalimantan/Borneo, with one of the highest diversity found in East Kalimantan. Furthermore, Kurniawan and Parikesit (2008) reported that plant diversity and composition in an area depends on some factors including altitude, humidity, nutrient availability, illumination, topography and soil types.

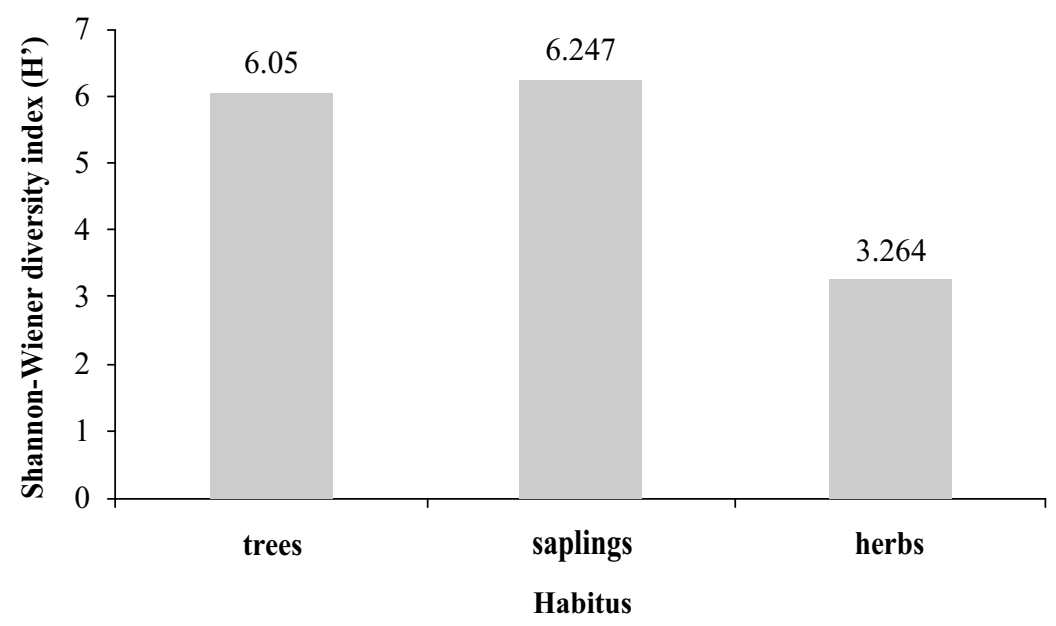

Figure 2 Shannon - Wiener diversity index $\left(\mathrm{H}^{\prime}\right)$ of tree, sapling and herb in Forest of Besiq Bermai 


\section{Floristic Composition of Trees}

This study showed that, there were 93 species of trees from 48 genera and 22 families in Besiq Bermai Forest. Some of the most important species for tree included Dillenia excelsa, Sysygium sp., and Shorea parvifolia (Fig. 3). Dillenia excelsa was the most important species in terms of basal area based on RC, however, it had the lowest number of plants. Syrygium sp. was the second most important species in terms of species frequency, which was often found in plots at the study site. Shorea parvifolia ranked number three in ten most important species, it had the largest number of plants (Fig. 3). Genus of Shorea dominated the study site with nine species, and three of the species were in the list of ten most important species in terms of their abundance.

The present study also demonstrated that the most important plant family for trees was Dipterocarpaceae, followed by Lauraceae and Myrtaceae (Fig. 4). Dipterocarpaceae also had the largest number of species (17 species) including the genera Shorea, Hopea and Dipterocarpus; followed by Lauraceae with 12 species (i.e genera of Eusideroxylon, Litsea and Actinodaphne), Burseraceae with seven species (i.e. genera of Canarium, Dacryodes and Santiria), Leguminosae with seven species (i.e. genera of Sindora, Koompassia and Dialium), and Myrtaceae with six species in a single genus of Syzygium.

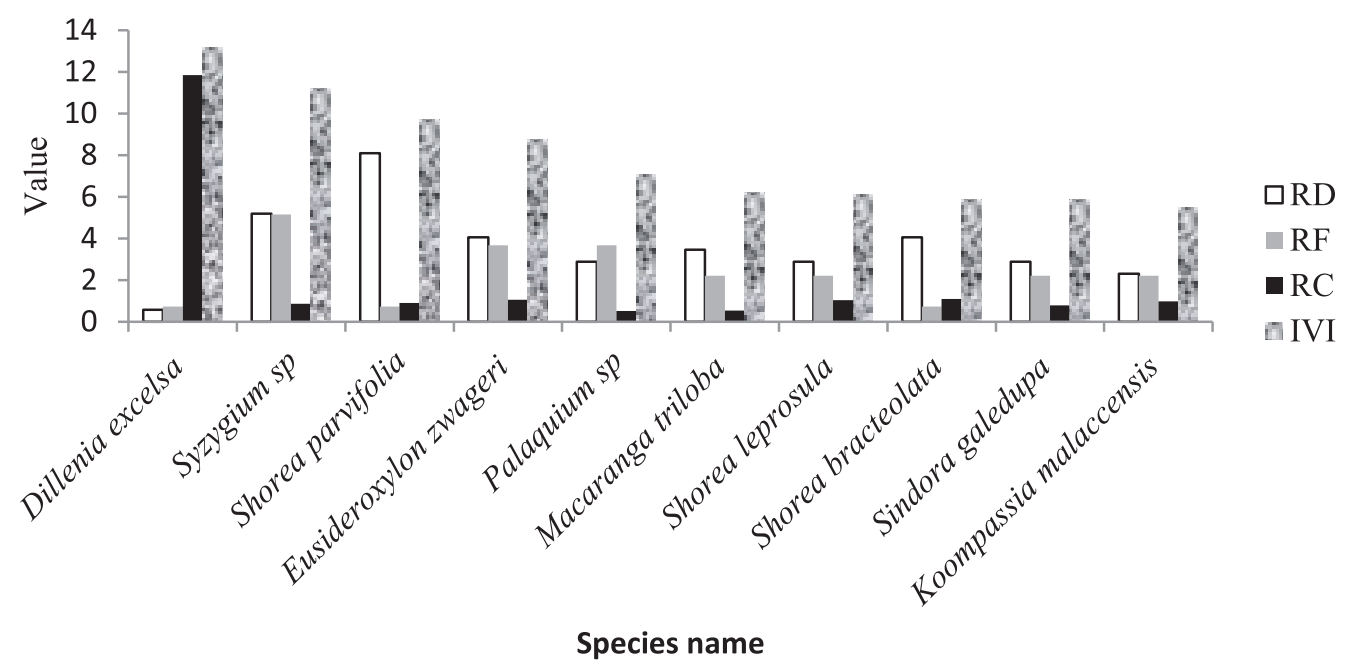

Figure 3 Ten most important tree species in Besiq Bermai Forest

(Note: RD = Relative Density; RF = Relative Frequency; RC = Relative Dominance; IVI=Important value Index)

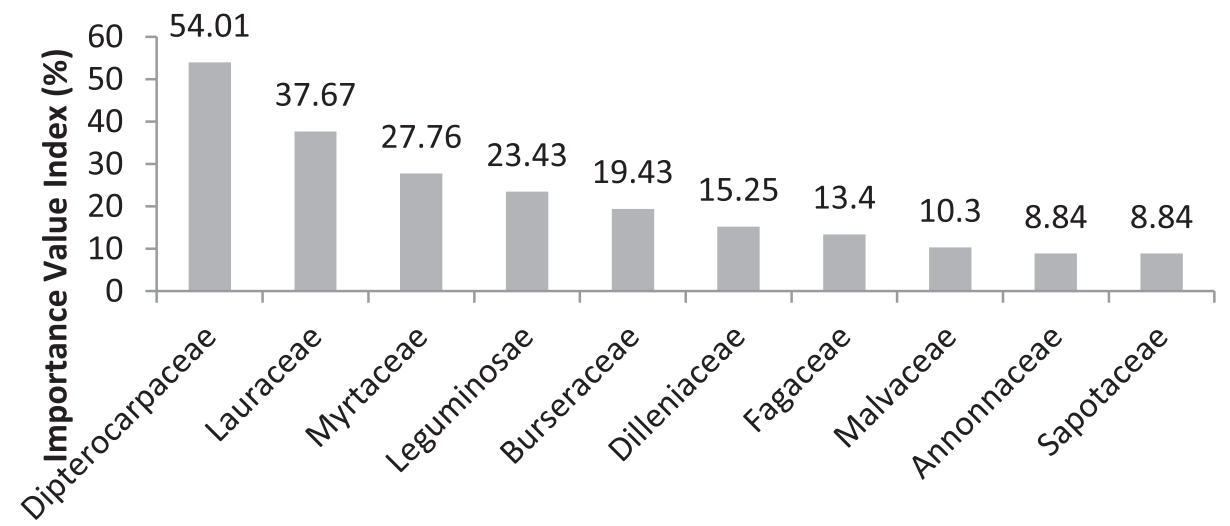

Plant families

Figure 4 Ten most important plant families in the category of trees in Besiq Bermai Forest. Family important value is the sum of Important Value Index of all species contained in a single family. 
The results of this study was similar with other studies that showed that the most important family in other forests within Borneo/Kalimantan was Dipterocarpaceae. Kartawinata et al. (2008) reported that a family with the highest important value index in the lowland Dipterocarp forest at Wanariset Saboja, East Kalimantan, was Dipterocarpaceae. Arbainsyah et al. (2014) also reported that the most abundant seedling of the species in the primary forest in Labanan East Kalimantan was Dipterocarpaceae. Budiharta (2010) also showed that Dipterocarpaceae dominated the biodiversity protection area of Lubuk Kakap, West Kalimantan. Saner et al. (2012) also reported that tropical lowland dipterocarp rain forests in Sabah, Malaysian Borneo, was also dominated by Dipterocarp species. The dominance of Dipterocarpaceae in the forests might be in part due to its mast fruiting, the synchronous production of fruits in multi-years cycle at intervals of several years. This irregular fruiting may enhance pollination efficiency, seed survival, and seedling establishment (Visser et al. 2011; Rodriguez et al. 2013; Oshima et al. 2015). The predator satiation hypothesis stated that starvation of seed predators in time of no production of fruits decreases seed predation and therefore, increase tree regeneration (Visser et al. 2011).

\section{Floristic Composition of Saplings}

The present study also revealed the floristic composition of saplings. The most important species for saplings was Macaranga triloba in terms of basal area, followed by Shorea parvifolia. Syaygium sp. and Xylopia malayana (Fig. 5). The pattern of the most important species for trees

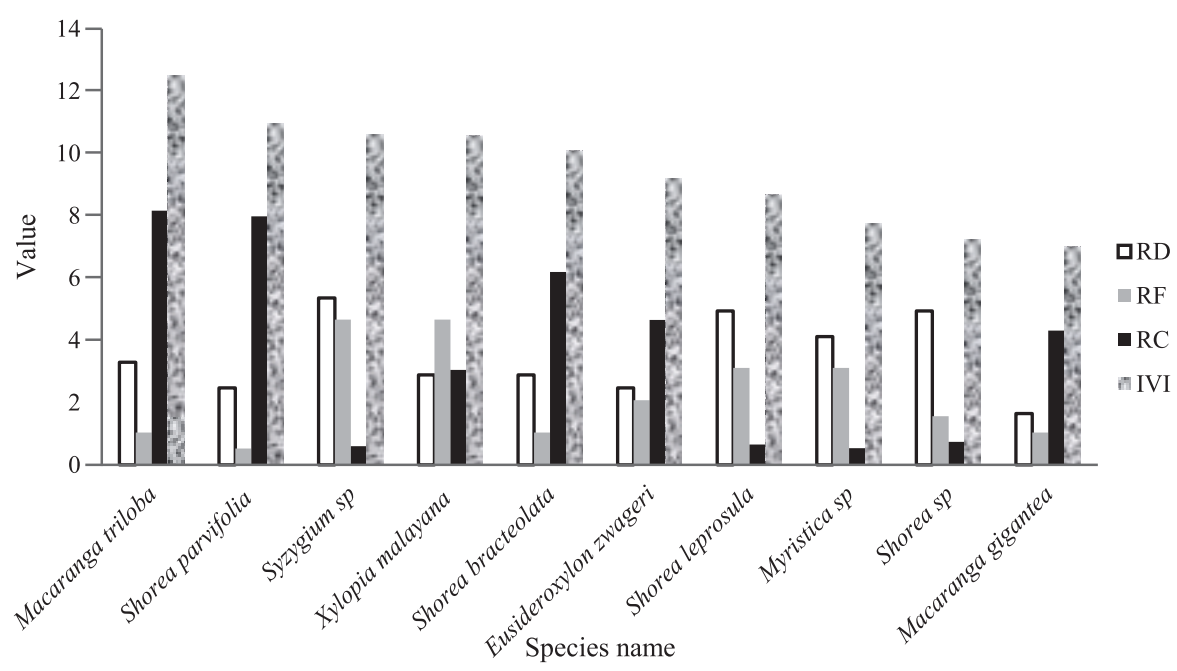

Figure 5 Ten most important species for sapling in Besiq Bermai Forest

(Note: RD=Relative Density; RF=Relative Frequency; RC=Relative Dominance; IVI=Important value Index)

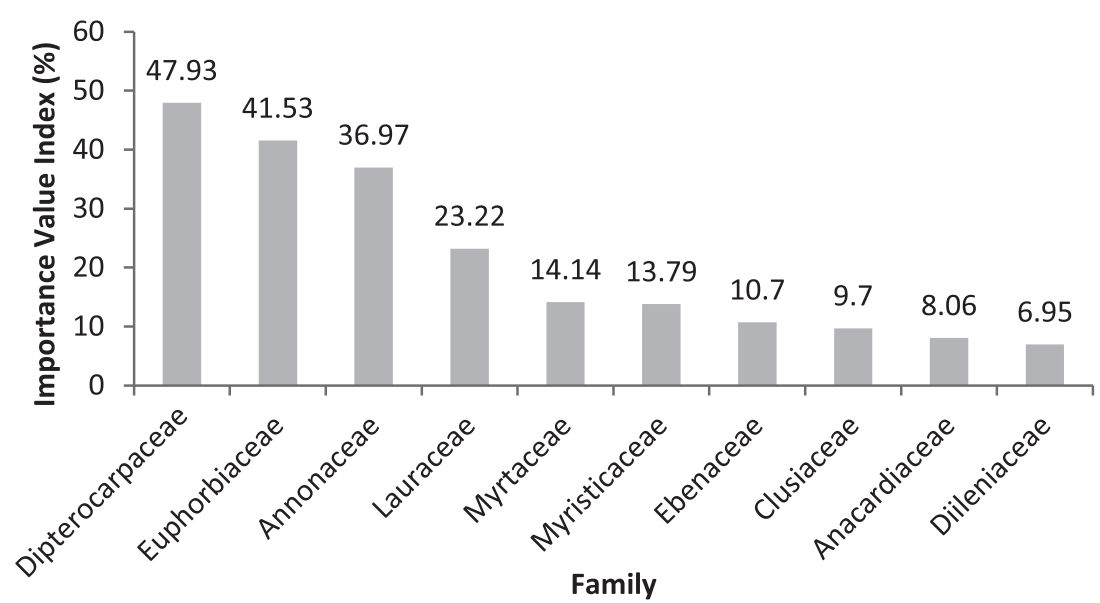

Figure 6 Ten most important plant families in Besiq Bermai Forest in the category of saplings. Family important value is the sum of Important Value Index of all species contained in a single family. 
and saplings in this study was different. Budiharta (2010) also showed variation of pattern of the flora composition between tree and saplings in West Kalimantan that might be due to the difference in mast flowering and fruiting frequencies between species which influence the survival of seedlings.

The most important family for saplings was Dipterocarpaceae, followed by Euphorbiaceae and Annonaceae (Fig. 6). Dipterocarpaceae also had the highest number of species (10 species) including the genera Shorea and Hopea; followed by Euphorbiaceae with 9 species (i.e genera of Xylopia and Monocarpia).

\section{Floristic Composition of Understory}

The results of the study also showed the flora composition for understory. The most important species for understory was Calathea sp., followed by Pandanus sp., and Alpinia sp. (Fig. 7). Analysis of compositional diversity of understory flora in the study showed that the understory flora was dominated by Calathea sp. that belongs to the plant family Marantaceae (Fig. 7). The dominance of Calathea in the shaded forest canopy with low light intensity in the forest floor in this study may be related to its low tolerance of light intensity and its capacity to grow in shaded areas with low

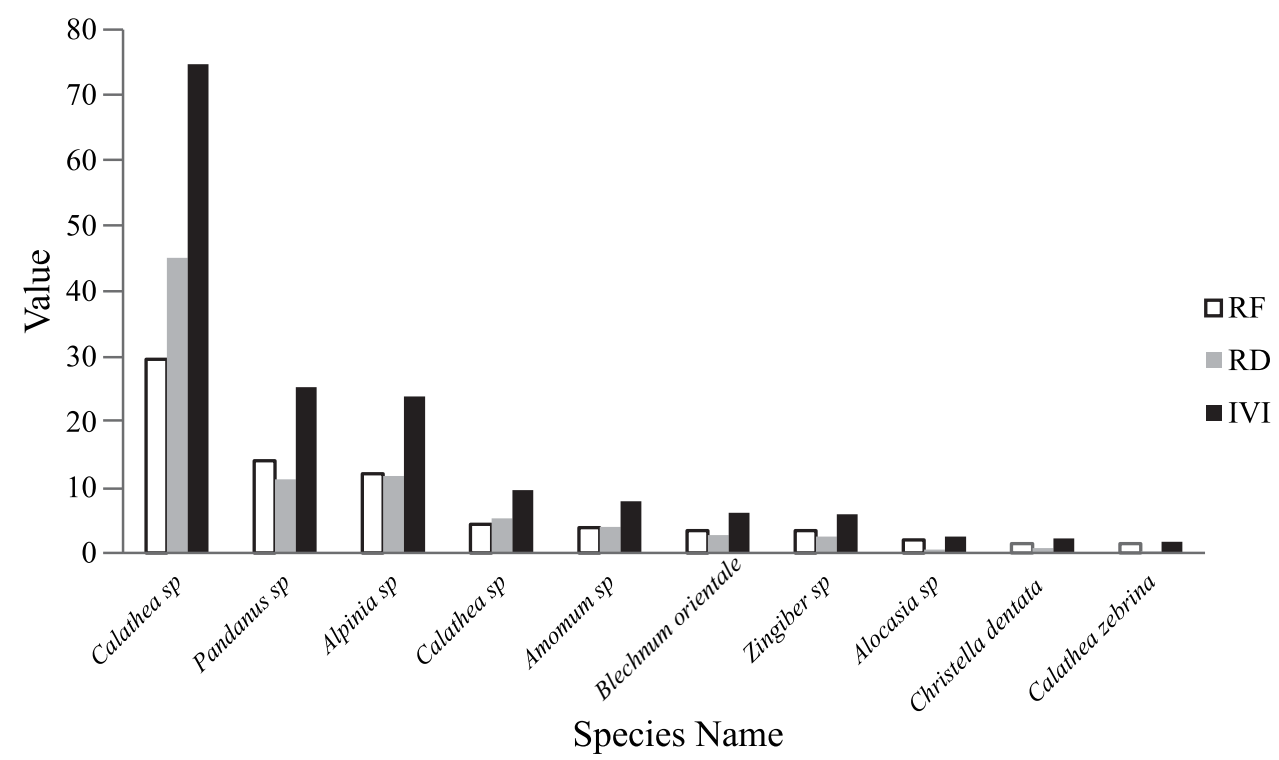

Figure 7 Ten most important species for understory

(Note: $\mathrm{RD}=$ Relative Density; RF=Relative Frequency; IVI=Important value Index)

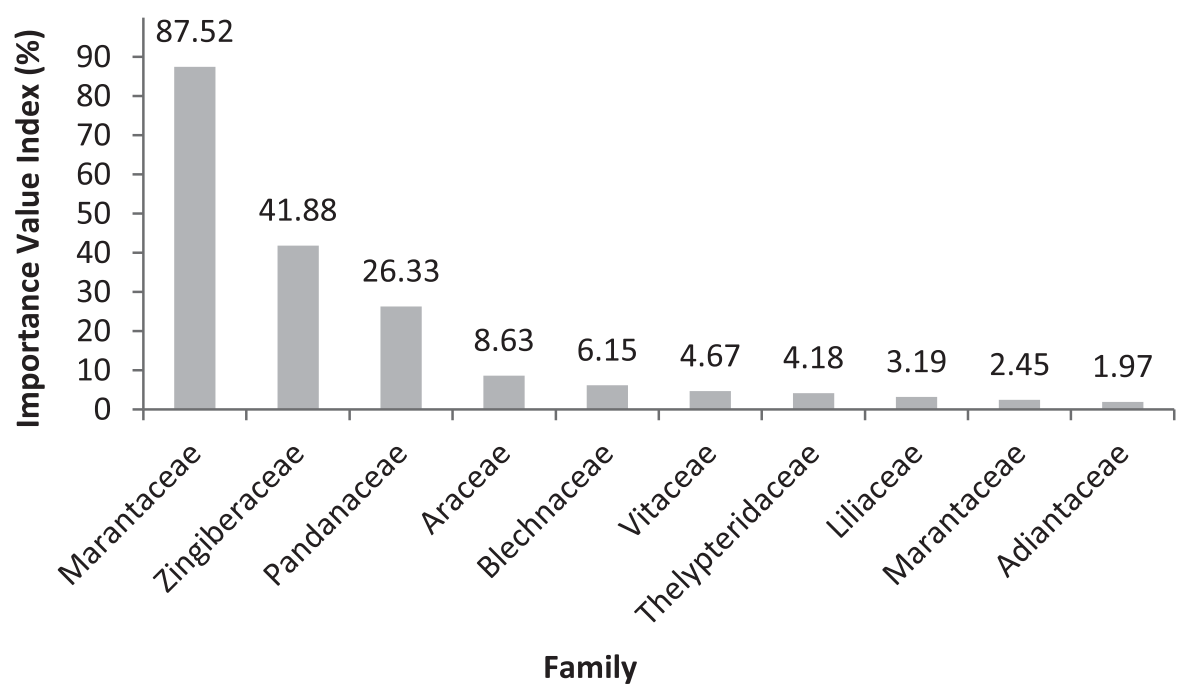

Figure 8 Ten most important families for understory 
light intensity. Matlaga (2008) reported that clonal offspring of Calathea grew and survived well in shaded understory.

The most important family for understory in Besiq Bermai forest was Marantaceae, followed by Zingiberaceae and Pandanaceae (Fig. 8). In terms of the number of species, Marantaceae and Zingiberaceae were high with six (6) species from the genera Calathea, Phrynium and Stachyphrynium. Zingiberaceae at the study site consisted of 6 species from the genera Zingiber, Amomum and Alpinia.

\section{Ecology of Flora in Besiq Bermai Forest}

The establishment of flora in their habitats showed the adaptation of the flora to their environment. The diversity and distribution of many plant species are influenced by the ecological factors including edaphic factors (Heineman et al.2015; Vleminckx et al. 2015).

Through Principal Component Analysis (PCA), environmental (soil) factors consisting of five soil variables $(\mathrm{pH}$, organic $\mathrm{C}$, total $\mathrm{N}$, organic matter, and $\mathrm{C} / \mathrm{N}$ ratio) and environment variables (temperature, humidity, light intensity and elevation) could be classified into two principal components. The two principal components explains $68.8 \%$ of all edaphic factors measured. The first component explained $35.4 \%$ of all edaphic factors measured, while the second component only explained $33.4 \%$. This showed that the first component provided more information than the second component in describing and identifying environmental conditions in Besiq Bermai Forest in which many plant species occured. $\mathrm{C} / \mathrm{N}$ ratio of soils was the most influential variable towards the factors in the first component (PC1), while total $\mathrm{N}$ was the most influential variable towards the factors in the second component (PC2) (Table 1).

The model of the habitat of flora in Besiq Bermai Forest with its edaphic factors can be formulated based on Table 1. PC1 $=0.27 \mathrm{pH}+$ $0.35 \mathrm{OC}+0.17 \mathrm{TN}+0.36 \mathrm{OM}+0.37 \mathrm{C} / \mathrm{N}$ R; $\mathrm{PC} 2=-0.35 \mathrm{pH}+0.26 \mathrm{OC}+0.46 \mathrm{TN}+0.27 \mathrm{OM}$ $-0.10 \mathrm{C} / \mathrm{N}$ R. Each soil variable in PC 1 and in PC2 was not strongly correlated (Table 1).

There are many soil factors (variables) that influence the diversity and distribution of plant species, such as organic matter, exchangable cation, soil types and other soil factors. These soil factors form the characteristics of habitats and can be the determinants of the distribution and diversity of flora in their habitats (Peña-Claros et al. 2012; Vleminckx et al. 2015; Zhang et al. 2016). Some studies have shown that species diversity and composition in some ecosystems were related to the site characteristic including edaphic factors (Gautam et al. 2016; Khan et al. 2017). Gautam et al. (2016) showed that the most important factors influencing tree diversity in the north Indian moist deciduous forests were exchangeable base cations and phosphorous. Furthermore, PeñaClaros et al. (2012) showed that in the dry forest in Bolivia, correlation between soil characteristics and plant diversity was more related to $\mathrm{Ca}$, organic matter, $\mathrm{N}, \mathrm{Mg}$ and $\mathrm{Na}$.

In this study, the first factor that mostly influenced the diversity and establishment of flora in Besiq Bermai forest was total $\mathrm{N}$ in the soil. Nitrogen is an essential element for the growth and development of plants. The availability of $\mathrm{N}$ in the soil affect the growth, development, and establishment of flora in Besiq Bermai forest.

Table 1 Eigen value of soil elements in Besiq Bermai Forest

\begin{tabular}{lcc}
\hline & PC1 (component factors 1) & PC2 (component factors 2) \\
\hline Eigen value & 5.11 & 2.92 \\
Proportion & 0.3 & 0.17 \\
Cumulatif & 0.3 & 0.47 \\
Variabels: & & -0.35 \\
pH $(\mathrm{pH})$ & 0.27 & 0.26 \\
Organic C $(\mathrm{OC})$ & 0.35 & 0.46 \\
Total N (TN) & 0.17 & 0.27 \\
Organic matter $(\mathrm{OM})$ & 0.36 & -0.10 \\
C/N ratio $(\mathrm{C} / \mathrm{N} \mathrm{R})$ & 0.37 & \\
\hline
\end{tabular}


The second factor that influenced the occurence and establishment of flora in Besiq Bermai forest was $\mathrm{C} / \mathrm{N}$ Ratio. $\mathrm{C} / \mathrm{N}$ ratio shows the rate of decomposition of organic matter and mineralisation of nutrient elements in soils (Tisdale 1985). Ross et al. (2011) showed the relationship between the establishment of plant species and $\mathrm{C} / \mathrm{N}$ ratio indicating that $\mathrm{C} / \mathrm{N}$ ratio influenced the diversity of plant species in their habitat. The $\mathrm{C} / \mathrm{N}$ ratio indicates the decomposition of organic matter and in relation to the nutrient provision in soils plays key roles in the function of forest ecosystem for the establishment of the flora.

\section{Implications for Conservation}

The present study has shown the flora diversity, compositon, and ecology in Besiq Bermai forest. The selected study site was a coal mining area. With the obligation and responsibility to rehabilitate and restore sites after the coal is mined, the results of the present study is required for the reconstruction of the sites and reverting the flora diversity and composition, and ecology of the forest.

The present study contributes to support the management of biodiversity and forest conservation after coal mining. The study is also required for rehabilitation program of degraded post mining lands. The soil chemistry that most influences the existence of species of the Shorea family is $\mathrm{C} / \mathrm{N}$ ratio and total nitrogen. The $\mathrm{C} / \mathrm{N}$ ratio can explain the speed of overhauling organic matter in the form of chemical-bound nutrient decomposition and mineralization in the form of complex compounds. When planting at post-mining areas, it's advisable to use additional organic materials, such as compost, manure, or the addition of calcium, depending on the deficiency in organic matter and acidity level of the soil.

There are several species included in the IUCN red list, with critically endangered category, namely Shorea leprosula, Dipterocarpus cornutus and Hopea ferruginea. The dominance of the various Shorea plants that are included in the IUCN redlist, as well as other dominant local species should be given priority as the species used in the restoration of post-mining areas due to their ecological suitability with forest ecosystems in the study sites.

\section{CONCLUSION}

The diversity of plants in Besiq Bermai forest was relatively high, with Shannon-Wiener diversity index $\left(\mathrm{H}^{\prime}\right)$ 6.05, 6.25 and 3.26 for tree, sapling and understory, respectively. Dipterocarpaceae was the most commmon plant family for tree and saplings, while Marantaceae was the dominant family for understory. Edaphic factors that had the highest influence on the occurence and establishment of flora in Besiq Bermai forest were total $\mathrm{N}$ and $\mathrm{C} / \mathrm{N}$ ratio. The present study has an implication to support management of biodiversity and forest conservation.

\section{ACKNOWLEDGEMENTS}

We would like to thank the team of exploration for the assistance in the field. This research was supported by Research Program on Plant Diversity and Habitat in coal mining exploration areas of PT. Bharinto Ekatama and PT. Indo Tambangraya Megah Tbk branch, West Kutai, East Kalimantan.

\section{REFERENCES}

Addo-Fordjour P, Obeng S, Anning AK, Addo MG. 2009. Floristic composition, structure and natural regeneration in a moist semi-deciduous forest following anthropogenic disturbances and plant invasion. Int J Biodivers Conserv 1(2):021-037.

Arbainsyah, de Longh HH, Kustiawan W, de Snoo GR. 2014. Structure, composition and diversity of plant communities in FSC-certified, selectively logged forests of different ages compared to primary rain forest. Biodivers Conserv 23(10):2445-72.

Ashton MS, Gunatilleke CVS, Gunatilleke IAUN, Singhakumara BMP, Gamage S, Shibayama T, Tomimura C. 2014. Restoration of rain forest beneath pine plantations: A relay floristic model with special application to tropical South Asia. Forest Ecol Manag 329:351-9.

Bruhl CA, Eltz T. 2010. Fuelling the biodiversity crisis: Species loss of ground-dwelling forest ants in oil palm plantations in Sabah, Malaysia (Borneo). Biodivers Conserv 19(2):519-29.

Budiharta S. 2010. Floristic composition at biodiversity protection area in Lubuk Kakap, District of Ketapang, West Kalimantan. Biodiversitas 11(3):151-6. 
Busch J, Ferretti-Gallon K. 2017. What drives deforestation and what stops it? A meta-analysis. Rev Environ Econ Policy 11(1):3-23.

de Bruyn M, Stelbrink B, Morley RJ, Hall R, Carvalho GR, Cannon CH, Maiorano L. 2014. Borneo and Indochina are major evolutionary hotspots for Southeast Asian biodiversity. Syst Biol 63(6):879901.

Feroz SM, Mamun AA, Kabir ME. 2016. Composition, diversity and distribution of woody species in relation to vertical stratification of a tropical wet evergreen forest in Bangladesh. Glob Ecol Conserv 8:144-53.

Gaither MR, Rocha LA. 2013. Origins of species richness in the Indo-Malay-Philippine biodiversity hotspot: Evidence for the centre of overlap hypothesis. J Biogeogr 40:1638-48.

Gautam MK, Manhas RK, Tripathi AK. 2016. Overstory structure and soil nutrients effect on plant diversity in unmanaged moist tropical forest. Acta Oecol 75:43-53.

Gaveau DL, Kshatriya M, Sheil D, Sloan S, Molidena E, Wijaya A, Guariguata MR. 2013. Reconciling forest conservation and logging in Indonesian Borneo. PLoS ONE 8(8):e6988.

Gaveau DLA, Sheil D, Husnayaen, Salim MA, Arjasakusuma S, Ancrenaz M, Pacheco P, Meijaard E. 2016. Rapid conversions and avoided deforestation: Examining four decades of industrial plantation expansion in Borneo. Sci Rep:1-13.

Giliba RA, Boon EK, Kayombo CJ, Musamba EB, Kashindye AM, Shayo PF. 2011. Species composition, richness and diversity in Miombo Woodland of Bereku Forest Reserve, Tanzania. J Biodivers 2(1):1-7.

Gilman AC, Letcher SG, Fincher RM, Perez AI, Madell TW, Finkelstein AL, Corrales-Araya F. 2016. Recovery of floristic diversity and basal area in natural forest regeneration and planted plots in a Costa Rican wet forest. Biotropica 48(6):798-808.

Godoong E, Wai YS, Hector A. 2014. Forest structure dynamics in lowland and hill dipterocarp logged forests of Sabah (North Borneo), Malaysia. In: Regional Conference on Protected Area and Biodiversity Management in Southeast Asia.

Guhardja E, Fatawi M, Sutisna M, Mori T, Ohta S. 2012. Rainforest ecosystems of East Kalimantan: El Niño, drought, fire and human impacts. Tokyo (JP): Springer Japan.

Hansen M, Stehman S, Potapov P, Arunarwati B, Stolle F, Pittman K. 2009. Quantifying changes in the rates of forest clearing in Indonesia from 1990 to 2005 using remotely sensed data sets. Environ Res Lett 4(3):112.

Heineman KD, Russo SE, Baillie IC, Mamit JD, Chai PPK, Chai L, Ashton PS. 2015. Influence of tree size, taxonomy and edaphic conditions on heart rot in mixed-dipterocarp Bornean rainforests: Implications for aboveground biomass estimates. Biogeosci Discuss 12(17):6821-61.

Huang J, Liu C, Zhang J, Lu X, Ma K. 2016. Diversity hotspots and conservation gaps for the Chinese endemic seedflora. Biol Conserv 198:104-12.

Kartawinata K, Purwaningsih, Partomihardjo T, Yusuf R, Abdulhadi R, Riswan S. 2008. Floristics and structure of a lowland Dipterocarp Forest at Wanariset Samboja, East Kalimantan, Indonesia. Reinwardtia 12(4):301-23.

Kebede B, Soromessa T, Kelbessa E. 2016. Floristic composition and community types of Gedo Dry Evergreen Montane Forest, West Shewa, Ethiopia. Acta Ecol Sin 36:392-400.

Kettle CJ. 2012. Seeding ecological restoration of tropical forests: Priority setting under REDD+. Biol Conserv 154:34-41.

Khan SM, Page S, Ahmad H, Shaheen H, Harper DM. 2012. Vegetation dynamics in the Western Himalayas, diversity indices and climate change. Sci Tech and Dev 31(3):232-243.

Khan M, Khan SM, Ilyas M, Alqarawi AA, Ahmad Z, AbdAllah EF. 2017. Plant species and communities assessment in interaction with edaphic and topographic factors; An ecological study of the Mount Eelum District Swat, Pakistan. Saudi J Biol Sci 24:778-86.

Kjeldahl J. 1883. Neue methode zur bestimmung des sticksstoffs in organischen korpern. [New method for the deteremination of nitrogen in organic substances]. Fresenius J Anal Chem 22(1):366-83.

Kurniawan A, Parikesit 2008. Persebaran jenis pohon di sepanjang faktor lingkungan di Cagar Alam Pananjung Pangandaran, Jawa Barat. [Tree species distribution along the environmental gradients in Pananjung Pangandaran Nature Reserve, West Java]. Biodiversitas 9(4):275-79.

Lukácz BA, Sramkó G, Molnár VA. 2013. Plant diversity and conservation value of continental temporary pools. Biol Conserv 158:393-400.

Malouin C, Larocque G, Doyle M, Bell F, Dacosta J, Liss K. 2015. Considerations of ecosystem services in ecological forest management. In: Larocque $G$, editor. Ecological Forest Management Handbook. Florida (US): CRC Press. p. 107-38.

Marchese C. 2015. Biodiversity hotspots: A shortcut for a more complicated concept. Glob Ecol Conserv 3:297-309.

Margono BA, Potapov PV, Turubanova S, Stolle F, Hansen MC. 2014. Primary forest cover loss in Indonesia over 2000-2012. Nat Clim Change 4:1-6.

Matlaga DP. 2008. The importance of sexual and clonal reproduction for population dynamics in the understory herb Calathea marantifolia (Marantaceae). Miami (US): The University of Miami. 
Meng J, Lu Y, Lei X, Liu G. 2011. Structure and floristics of tropicalforests and their implications for restoration of degraded forests of China's Hainan Island. Trop Ecol 52(2):177-91.

Nurfadilah S. 2015. Diversity of epiphytic orchids and host trees (phorophytes) in secondary forest of Coban Trisula, Malang Regency, East Java, Indonesia. BIOTROPIA 22(2):120-8

Oshima C, Tokumoto Y, Nakagawa M. 2015. Biotic and abiotic drivers of dipterocarp seedling survival following mast fruiting in Malaysian Borneo. J Trop Ecol31(2):129-37.

Peña-Claros M, Poorter L, Alarcón A, Blate G, Choque U, Fredericksen TS, Toledo M. 2012. Soil effects on forest structure and diversity in a moist and a dry tropical forest. Biotropica 44(3):276-83.

Reddy CS, Shilpa B, Giriraj A, Reddy KN, Rao KT. 2008. Structure and floristic composition of tree diversity in tropical dry deciduous forest of Eastern Ghats, Southern Andhra Pradesh, India. Asian J Sci Res 1(1):57-64.

Reddy CS, Shilpa B, Amarnath G, Pattanik. 2011. Structure and Floristic Composition of tree stand in tropical forest in the Eastern Ghats of Northern Andhra Pradesh, India. J Forest Res 22(4):491-500.

Richards PW. 1952. The tropical rain forest: An ecological study. New York (US): Cambridge University Press.

Rodriguez A, Alquezar B, Pena L. 2013. Fruit aromas in mature fleshy fruits as signals of readiness for predation and seed dispersal. New Phytol 197(1):3648.

Ross DS, Bailey SW, Lawrence GB, Shanley JB, Fredriksen G, Jamison AE, Brousseau PA. 2011. Near-surface soil carbon, carbon/nitrogen ratio and tree species are tightly linked across Northeastern United States Watersheds. Forest Sci 57(6):460-9.
Saner P, Loh YY, Ong RC, Hector A. 2012. Carbon stocks and fluxes in tropical lowland Dipterocarp rainforests in Sabah, Malaysian Borneo. PLoS ONE 7(1):e29642.

Stibig HJ, Belward AS, Roy PS, Rosalina-Wasrin U, Agrawal S, Hildanus JPK, ... Giri C. 2007. A land-cover map for South and Southeast Asia derived from SPOTVEGETATION data. J Biogeogr 34:625-37.

Tisdale SL, Nelson WL, Beaton JD, Havlin J. 1985. Soil fertility and fertilizers, $4^{\text {th }}$ edition. Basingstoke (UK): Macmillan.

Visser MD, Jongejans E, van Breugel M, Zuidema PA, Chen YY, Kassim AR, de Kroon H. 2011. Strict mast fruiting for a tropical dipterocarp tree: A demographic cost-benefit analysis of delayed reproduction and seed predation. J Ecol 99:1033-44.

Vleminckx J, Drouet T, Amani C, Lisingo J, Lejoly J, Hardy OJ. 2015. Impact of fine-scale edaphic heterogeneity on tree species assembly in a central African rainforest. J Veg Sci 26(1):134-44.

Walkley A, Black IA. 1934. An examination of Degtjareff method for determining soil organic matter and a proposed modification of the chromic acid titration method. Soil Sci 37:29-37.

Whitmore TC. 1988. Tropical rain forests of the Far East, $2^{\text {nd }}$ edition. English Language Book Society. Oxford (UK): Oxford University Press.

You H, Jin HY, Khaldi AH, Kwak MJ, Lee TY, Khaine IK, Woo SY. 2016. Plant diversity in different bioclimatic zones in Tunisia. J Asia Pac Biodivers $9(1): 56-62$.

Zhang C, Li X, Chen L, Xie G, Liu C, Pei S. 2016. Effects of topographical and edaphic factors on tree community structure and diversity of subtropical mountain forests in the Lower Lancang River Basin. Forests 7(10):222. 